
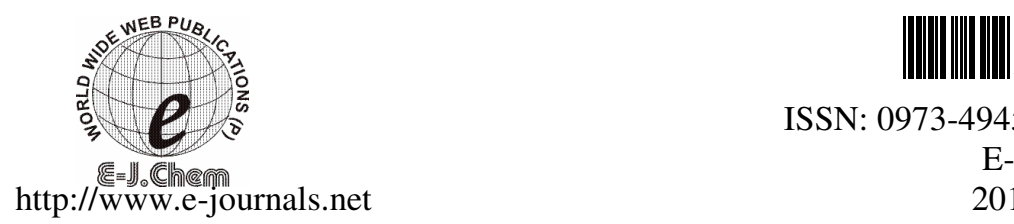

ISSN: 0973-4945; CODEN ECJHAO

E-Journal of Chemistry

2010, 7(S1), S587-S593

\title{
Assessment of Water Pollution in Tipparthy Revenue Sub-Division, Nalgonda (District), Andhra Pradesh, India
}

\author{
MEDIKONDU KISHORE* ${ }^{*}$ and Y. HANUMANTHARAO ${ }^{\S}$ \\ Department of chemistry, Acharya Nagarjuna University Nuzvid campus \\ Nuzvid, Krishna (Dist), Andhra Pradesh, India \\ ${ }^{\S}$ Department of Chemistry, Andhra Loyola College (Autonomous), \\ Vijayawada, Krishna (Dist). Andhra Pradesh, India \\ medikissi@gmail.com
}

Received 30 April 2010, Accepted 20 June 2010

\begin{abstract}
A systematic study has been carried out to explore the physicochemical characteristics of drinking water sources of Tipparthy revenue sub-division, Nalgonda (District), Andhra Pradesh, India. Totally 49 water samples were collected from the different locations (22 villages) of the study area including bore well, open well and hand pump water and analyzed for $\mathrm{pH}, \mathrm{EC}$, TDS, turbidity, total hardness, fluoride, chloride, nitrate, nitrite, sulphate, phosphates, calcium, magnesium, sodium, potassium, Iron and dissolved oxygen. On an average, in almost all the samples, one or the other chemical constituent was beyond the permissible limits it was also concluded that water sources in the study area not fit for potability. Sodium absorption ratio (SAR) and water quality (WQI) studies indicate water available from all sources not fit for irrigation also. The study indicates the need for periodic monitoring of ground water in the study area.
\end{abstract}

Key words: Water quality, Physicochemical analysis, Water quality index, SAR

\section{Introduction}

Water is one of the essential components for the sustenance of life on earth. Among the various sources of water, ground water is said to be the safest water for drinking and domestic purposes. The quality of ground water is influenced by the nature of the sub surfaces as well as the environment where recharge takes place. Water used for industries, agricultural and human needs adds continuously contaminants to the ground water. It is reported that two third of all illness in India are related to water born diseases ${ }^{1-2}$.

Tipparthy revenue sub-division located in Nalgonda district, Andhra Pradesh, and the district was well known for endemic fluorosis ${ }^{3}$. From the literature it was confirmed that no body could study entire physicochemical analysis of all drinking water sources in this particular area ${ }^{4}$. So, in the light of the above, an attempt has been made to study the quality of drinking water from bore well (BW), hand pump (HP) and open well (OW) in and around Tipparthy revenue sub- division. 


\section{Geology of the study area}

The study area is located approximately $120 \mathrm{~km}$ away from the capital of Andhra Pradesh. Tipparthy division falls in the survey of India, toposheet No.56 P/10. The area lies between $16^{\circ} 40^{\prime} 30^{\prime \prime}$ and $16^{\circ} 45^{\prime} 30^{\prime \prime}$ latitudes and bounded by $79^{\circ} 31^{\prime} 00^{\prime \prime}$ and $79^{\circ} 40^{\prime} 00^{\prime \prime}$ longitudes. It is about $45 \mathrm{~km}$ south east of Nalgonda district head quarters of Andhra Pradesh. This area forms part of the past palnad basin and it is contact zone between quartizites of banganapalli and limestones of narji series of Kurnool formations. The soils of the catchment area can be broadly divided into 5 groups, namely medium block soil (12.0\%), deep block soil (29.0\%), mixed red and black soil (35.0\%), red sandy soil (20.0\%) and red loamy soil (4.0\%). As per census of 2001 the population of the revenue sub division has been recorded as 46,451.

A water quality index ${ }^{5}$ (WQI) is common with many other indices system transforms a group of water quality parameters to a common scale and combines them to form single number in accordance with a chosen method or model computation. The main objective of the WQI system is to use it as a preliminary means of assessing a water body for compliance with the standards adopted for designated classes of beneficial uses. A WQI is defined as the composite influence of different water quality parameters in the quantity of water ${ }^{6}$.

\section{Experimental}

Water samples have been collected manually from all existing sources of drinking water in the study and for the present investigation separate sets of samples were collected for chemical analysis from the source. The bottles for sample collection have been thoroughly cleaned by rinsing with $8 \mathrm{M} \mathrm{HNO}_{3}$, followed by repeated washing with double distilled water and they are further rinsed with sample water before collection. Physicochemical analysis was done by standard procedure ${ }^{7}$. The results were compared with $\mathrm{WHO}^{8}, \mathrm{USEPA}^{9}$ standards.

\section{Mathematical modeling}

Mathematical modeling ${ }^{10-11}$ offers more attractive studies, though it deviates much from real situations. The statistical parameters mean, minimum (min), maximum (max), sum and standard deviation (SD) were computed by using the experimental data.

\section{Water quality index}

WQI has been derived using the following formula:

$$
\mathrm{WQI}=(\mathrm{Qi} \mathrm{Wi} / \mathrm{Wi})
$$

Where Qi is the quality rating/sub index

The ground water quality rating was calculated by applying the formula:

$$
\mathrm{Qi}=(\mathrm{Mi}-\mathrm{Li}) /(\mathrm{Si}-\mathrm{Li}) \times 100
$$

Where $\mathrm{Mi}$ is the estimated value of the $\mathrm{i}^{\text {th }}$ parameter in the laboratory, $\mathrm{L}_{\mathrm{i}}$ is the ideal value of the $i^{\text {th }}$ parameter and $S_{i}$ is the standard values of the $i^{\text {th }}$ parameter. $W_{i}$ is the unit weight, which was calculated by the following formula: $\mathrm{Wi}=\mathrm{K} / \mathrm{Si}$

Where $\mathrm{K}$ (constant of proportionality $)=(1 / \mathrm{S} 1+1 / \mathrm{S} 2+\ldots \ldots . . \cdot 1 / \mathrm{Sn})$

$\mathrm{S}_{\mathrm{n}}$ is the standard values for different water quality parameters.

Sodium absorption ratio (SAR) studies ${ }^{6}$

SAR and $\% \mathrm{Na}$ were calculated from following method listed in Richard ${ }^{12}$ as follows:

$$
\begin{gathered}
\left.\mathrm{SAR}=\mathrm{Na}^{+} /\left[\left(\mathrm{Ca}^{2+}+\mathrm{Mg}^{2+}\right) / 2\right]\right]^{0.5} \\
\% \mathrm{Na}=\left[\left(\mathrm{Na}^{+}+\mathrm{K}^{+}\right) /\left(\mathrm{Ca}^{2+}+\mathrm{Mg}^{2+}+\mathrm{Na}^{+}+\mathrm{K}^{+}\right)\right] \times 100
\end{gathered}
$$

\section{Results and Discussion}

The findings of present investigation are summarized in Tables 1-3 were also made with WHO and USEPA drinking water standards. In the following text three types of waters are discussed in the order of BW, HP and OW respectively. 
Table 1. Physicochemical analysis of hand pump water

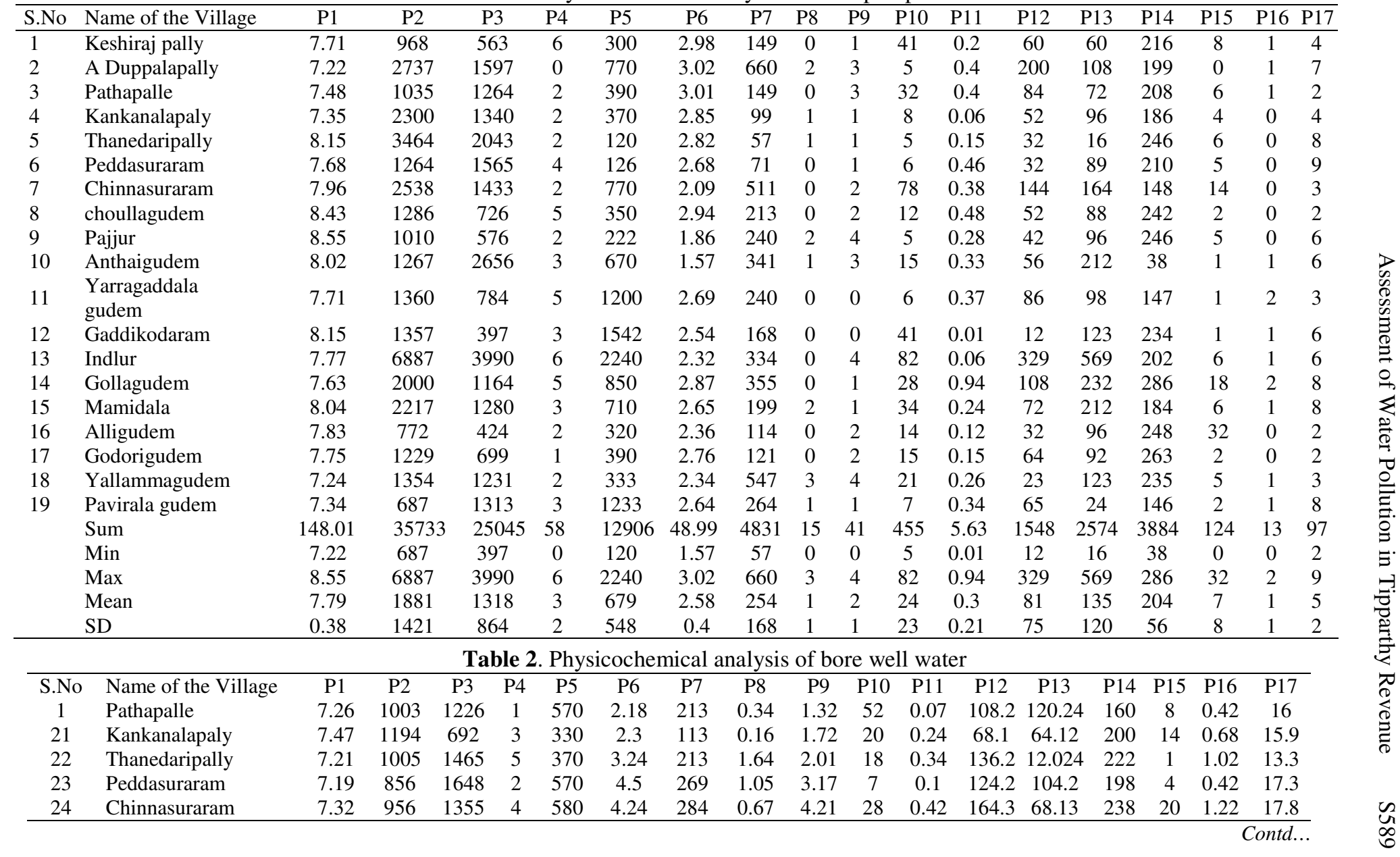




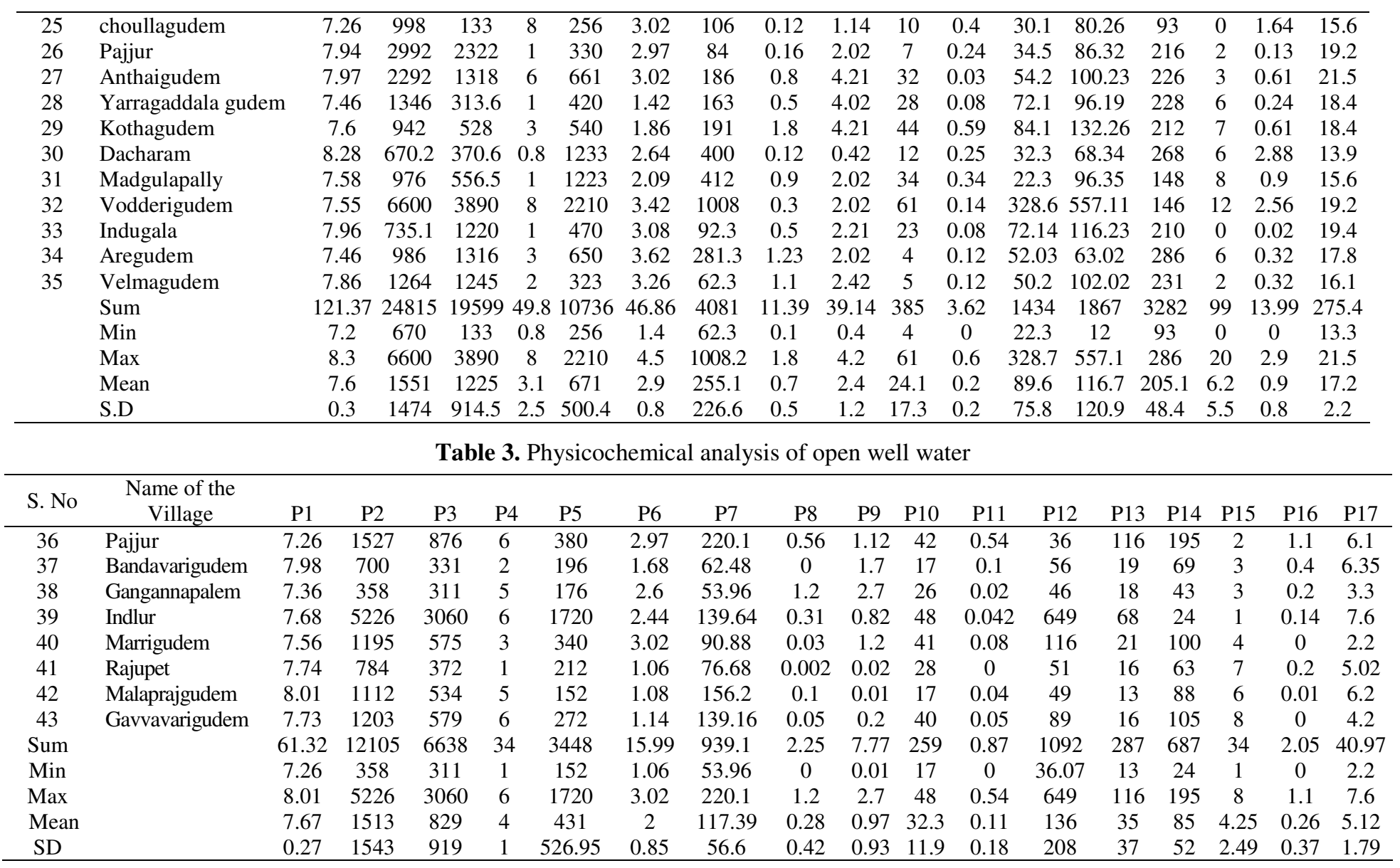

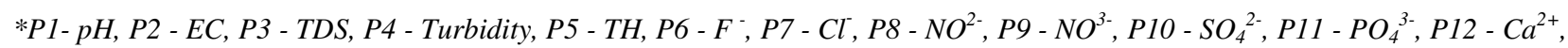

$\mathrm{P} 13-\mathrm{Mg}^{2+}, \mathrm{P} 14-\mathrm{Na}^{+} \mathrm{P} 15-\mathrm{K}^{+}, \mathrm{P} 16-\mathrm{Fe}^{2+}, \mathrm{P} 17-\mathrm{DO}$ 
The $\mathrm{pH}$ values vary from 7.20 to 8.30 , from 7.22 to 8.55 and from 7.26 to 8.36 in the samples from BW, HP and OW respectively. The higher electrical conductivity (EC) values in samples 26,27, 32 of bore wells water and in samples 2, 4, 5, 7, 13 of hand pump water and sample 39 of open well water clearly indicate that water is unfit for human consumption. Total dissolved solids (TDS) have varied from 133 to $3890 \mathrm{mg} / \mathrm{L}$, from 396 to $3990 \mathrm{mg} / \mathrm{L}$ and from 311 to $3060 \mathrm{mg} / \mathrm{L}$ in all three BW, HP and OW sources of drinking water. The results of total dissolved solids indicate that many samples of water from bore wells and hand pump contain high dissolved solids compared with that of open well water. Turbidity gives the water a cloudy appearance or shows up as dirty sediment. It was clearly indicates all the samples collected from study area were with in the permissible limit. Total hardness (TH) is the aesthetic objective is set at a maximum of $800 \mathrm{mg} / \mathrm{L}$.

In the study area, the total hardness of water from all the groundwater resources range between 256 to 2210,120 to 2240 and 60 to 730.8 as $\mathrm{CaCO}_{3}$ of samples from $\mathrm{BW}$, HP and OW respectively. The main source of fluoride and their concentrations in water is geological sources ${ }^{13-14}$. A colorless and odorless natural pollutant fluoride $\left(\mathrm{F}^{-}\right)$comes into contact with groundwater from its source of origin, the rock minerals. The maximum permissible limit in drinking water is $1.5 \mathrm{mg} / \mathrm{L}^{8-15}$. The concentration of fluoride ion in water samples has been analyzed by SPADNS technique ${ }^{7}$. The concentration of fluoride in all samples of study area has varied from 1.4 to $4.5 \mathrm{mg} / \mathrm{L}, 1.57$ to $3.02 \mathrm{mg} / \mathrm{L}$ and 1.06 to $3.02 \mathrm{mg} / \mathrm{L}$ of BW, HP and OW respectively. From the analytical study, 14 water samples from bore well, 19 from hand pump, 5 samples from open well water was falling in the range of 1.5 to $4.50 \mathrm{mg} / \mathrm{L}$ concentration of fluoride ion, but only 1 from bore well, 3 from open well water samples are within the permissible limit. The USEPA drinking water regulations recommended a maximum concentration of chloride $\left(\mathrm{Cl}^{-}\right)$ions is $250 \mathrm{mg} / \mathrm{L}$. High chloride contents were observed in samples 23,24,30,31,32 and 34 of bore well water and in sample $2,7,10,11,13,14,18$ and 19 of hand pump water. The higher concentration is usually indicative of polluted nature of water. The USEPA maximum contamination limit for nitrate is $10 \mathrm{mg} / \mathrm{L}$ and for nitrite is $1.0 \mathrm{mg} / \mathrm{L}$. Concentration of nitrate above $4 \mathrm{mg} / \mathrm{L}$ can cause methamaglobinemia (blue - baby disease) in children ${ }^{16}$. The concentrations of nitrate in all the samples in the study area are ranges from 0.4 to $4.2 \mathrm{mg} / \mathrm{L}, 0.42$ to $4.21 \mathrm{mg} / \mathrm{L}$ and 0.01 to 2.7 $\mathrm{mg} / \mathrm{L}$ in all the three BW, HP and OW sources respectively. The results indicate that the nitrate concentration is within the permissible limit in all water samples. The concentrations of nitrite $\left(\mathrm{NO}_{2}{ }^{-}\right)$in the study area are fall under the range of 0.1 to $1.8 \mathrm{mg} / \mathrm{L}, 0.08$ to $3.1 \mathrm{mg} / \mathrm{L}$ and 0.0 to $1.2 \mathrm{mg} / \mathrm{L}$. The sulphate $\left(\mathrm{SO}_{4}{ }^{2-}\right)$ contents in three sources have varied from 4 to $61 \mathrm{mg} / \mathrm{L}$, 5 to $82 \mathrm{mg} / \mathrm{L}$ and 17 to $48 \mathrm{mg} / \mathrm{L}$ respectively and values are within the permissible limit $(250$ $\mathrm{mg} / \mathrm{L})$. Phosphate $\left(\mathrm{PO}_{4}{ }^{3-}\right)$ values are also within the permissible limit.

The concentration of calcium $\left(\mathrm{Ca}^{2+}\right)$ has varied from 22.3 to $328.7 \mathrm{mg} / \mathrm{L}$, from 12.25 to $328.65 \mathrm{mg} / \mathrm{L}$ and 36.07 to $649.29 \mathrm{mg} / \mathrm{L}$. Higher value of calcium may be due to the presence of rock soil in the study area. The concentration of magnesium $\left(\mathrm{Mg}^{2+}\right)$ is higher in samples of $2,7,10,12,13,14,15$ and 18 of hand pump water, 20, 23, 29, 31, 32 and 35 of bore well water and $36 \& 39$ of open well water. This higher value of magnesium may be from leaching of rocks. The concentration of sodium $\left(\mathrm{Na}^{+}\right)$ranges from 93.0 to $280.0 \mathrm{mg} / \mathrm{L}$ in bore well, 38 to $286.0 \mathrm{mg} / \mathrm{L}$ in hand pumps and 24 to $195.0 \mathrm{mg} / \mathrm{L}$ in open well water respectively. The concentration of potassium $\left(\mathrm{K}^{+}\right)$ranges from 0 to $20.0 \mathrm{mg} / \mathrm{L}$ in bore wells, 0.00 to $32.00 \mathrm{mg} / \mathrm{L}$ in hand pumps and from 0.0 to $10.00 \mathrm{mg} / \mathrm{L}$ in open wells water respectively in the study area. Its concentration however is usually quite lower than that of sodium, calcium and magnesium. 
In the present study iron $\left(\mathrm{Fe}^{2+}\right)$ has varied from 0.0 to $2.9 \mathrm{mg} / \mathrm{L}$, from 0.04 to $2.4 \mathrm{mg} / \mathrm{L}$ and from 0.0 to $1.1 \mathrm{mg} / \mathrm{L}$ in all the samples. From the results it is concluded that most of the results well bellow the permissible limit ${ }^{9}$. Dissolved oxygen (DO) ranged from 2.20 to 9.20 $\mathrm{mg} / \mathrm{L}, 2.5$ to $9.5 \mathrm{mg} / \mathrm{L}$ and 2.2 to $7.60 \mathrm{mg} / \mathrm{L}$ in three deferent types of samples.

The sodium absorption ratio was calculated in given water samples, which provide a useful index of the sodium hazard present in soil and crops irrigated with such. A high sodium absorption ratio ( 2 to10) indicates little danger for sodium; medium hazard are between 7 and 18; high hazard between 11 and 26 and very high hazard above that. Lower the ionic strength of the solution, the greater sodium hazard for a given $\mathrm{SAR}^{5}$. The value of SAR in the ground water samples of the study area ranges from 23.18, 22.93 and 11.96 for HP, BW and OW. It was clearly indicates the ground water of the study area falls under the category of very high hazards. The value of sodium percentage in the ground water sample of the study area ranged from 53.21, 54.5 and 44.61 for three different types of samples. Based on this observations it was not quite safe for irrigation and potability ${ }^{12}$.

Prescribed water quality rating for drinking purposes is presented in broadly divided into five categories, excellent ( 0 to 25 ), good ( 26 to 50 ), poor (51 to 75$)$, very poor (76 to $100)$ and unfit for drinking water $((>100)$. It is observed that the WQI values for present investigation, hand pump water is 139.9 , for bore well water it was 130.6 indicating that Physico chemically water quality rated as ' unfit for drinking' purpose, where as for open well water it was rated as very poor for drinking purpose (90.1).

\section{Statistical analysis}

Positive correlation is obtained between EC and TH $(\mathrm{r}=0.99,0.99,1.0), \mathrm{Na}^{+}$and $\mathrm{Cl}^{-}$ $(\mathrm{r}=0.72,0.60,0.99)$ in hand pump, bore well and open well water samples. This indicates that conductivity depends on the salts of chloride of sodium and potassium. Total hardness showed positive correlations with EC, $\mathrm{Cl}^{-}(\mathrm{r}=0.9) \mathrm{Mg}^{2+}(\mathrm{r}=0.9)$ and $\mathrm{Na}^{+}(\mathrm{r}=0.6,0.5,0.9)$ in all three types of samples. This indicates that the hardness of water was contributed mainly by the salts of chlorides of $\mathrm{Na}^{+}, \mathrm{Mg}^{+}$and careful examination of results of water from study area reveals that a large number of pairs of parameters have high positive correlations $(\mathrm{r}>0.8)$. The significant correlations of EC, TDS with $\mathrm{TH}, \mathrm{SO}_{4}{ }^{2-}, \mathrm{Ca}^{2+}$ and $\mathrm{Mg}^{2+}$ indicate the presence of sulphates of calcium and magnesium. Compared with the other water quality parameters, EC and TDS are easily determinable. Hence on knowing this value exactly, we can calculate the other parameters, which are in good agreement with experimental data. So, this correlation determination provides quick monitoring of the quality of ground water.

\section{Conclusion}

The result of this study indicates that the quality of ground water varies from place to place. Higher values of certain parameters at certain bore wells open wells and hand pump water samples are not fit for drinking as such. The water quality index, sodium absorption ratio studies and $\% \mathrm{Na}$ studies indicates poor quality of water for drinking as well as agricultural purpose. Hence, proper care must be taken to avoid any contamination of ground water and its quality be monitored periodically.

\section{References}

1. Sowers M F R, Clark M K, Jannausch M L and Wallce R B, Am J Epidemiology, 1991, 133, 649-60. 
2. Shukla N, Moitra J K and Trivedi R C, Indian J Environ Prot., 1995, 15(12), 903-905.

3. Ramamohana Rao N V and Rajya Lakshmi K, Hyderabad Proceedings, 1974, 273-284.

4. Rafiuddin M K, Central ground water board ministry of water resources government of India; Ground Water Information Nalgonda District, Andhra Pradesh, 2007. http://cgwb.gov.in/District_Profile/AP/Nalgonda.pdf

5. $\quad$ Dasgupta A M, Indian J Environ Prot., 2002, 22(9), 1040-1046.

6. Moharir A, Indian J Environ Prot., 2002, 22(9), 961-969.

7. Standard Methods for the Examination of Water and Wastewater, (18 ${ }^{\text {th }}$ Ed.,) American Public Health Association, Washington DC 1992.

8. World Health Organization Guide Lines for Drinking Water Quality, $2^{\text {nd }}$ Ed., Health Criteria and Other Information, Geneva, 1996, 2, 231-237.

9. United states Environmental Protection Agency (USEPA). 1998a.EPCRA Section 313, Reporting Guidance for Food Processors, Washington DC, EPA Office of Pollution Prevention and Toxics.

10. Prasad N V V S, Defluoridation of potable water with low cost adsorbents, Ph D, thesis, Acharya Nagarjuna University, Andhra Pradesh, India, 2004.

11. Freund J E, Mathematical Statistics, $5^{\text {th }}$ Ed., Eastern Economy Editions, Prentice Hall of India, New Delhi, 1992.

12. Richards L A, Diagnosis and Improvement of Saline and Alkali Soil. U S Dept of Agriculture, Agriculture Handbook, 1954.

13. De A K, Environmental Chemistry, $6^{\text {th }}$ Ed., Wiley Estern India Ltd., 2008.

14. Kannan N, Karthikeyan G, Vallinayagam P and Tamil Selvan N, Indian J Environ Prot., 2004, 24 (11), 856 - 862.

15. WHO fluorides an human health monograph series No.59, World health organization, Geneva, 1970

16. National Research Council, Accumulation of Nitrate. National Academy of Sciences, Washington DC, 1972. 


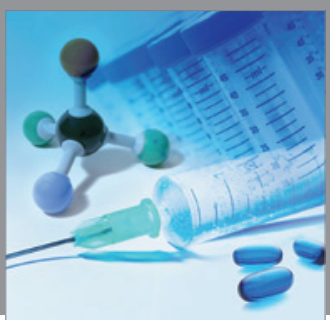

International Journal of

Medicinal Chemistry

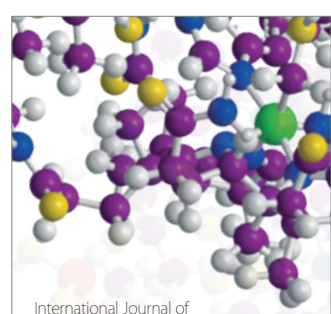

Carbohydrate Chemistry

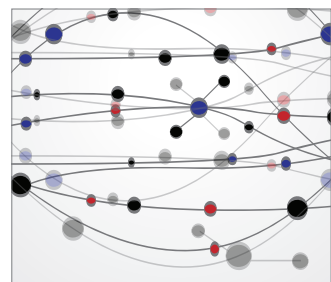

The Scientific World Journal
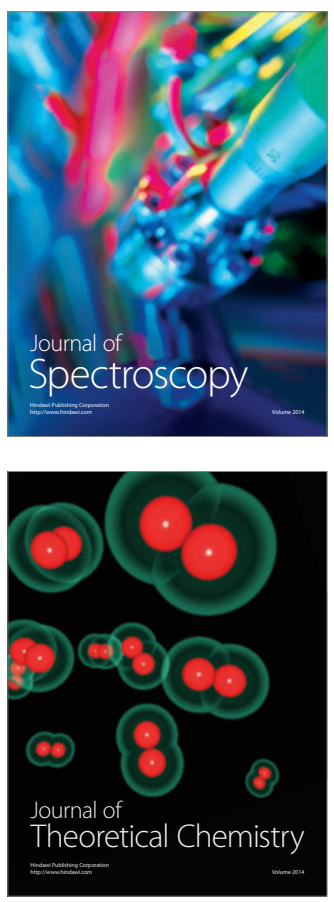
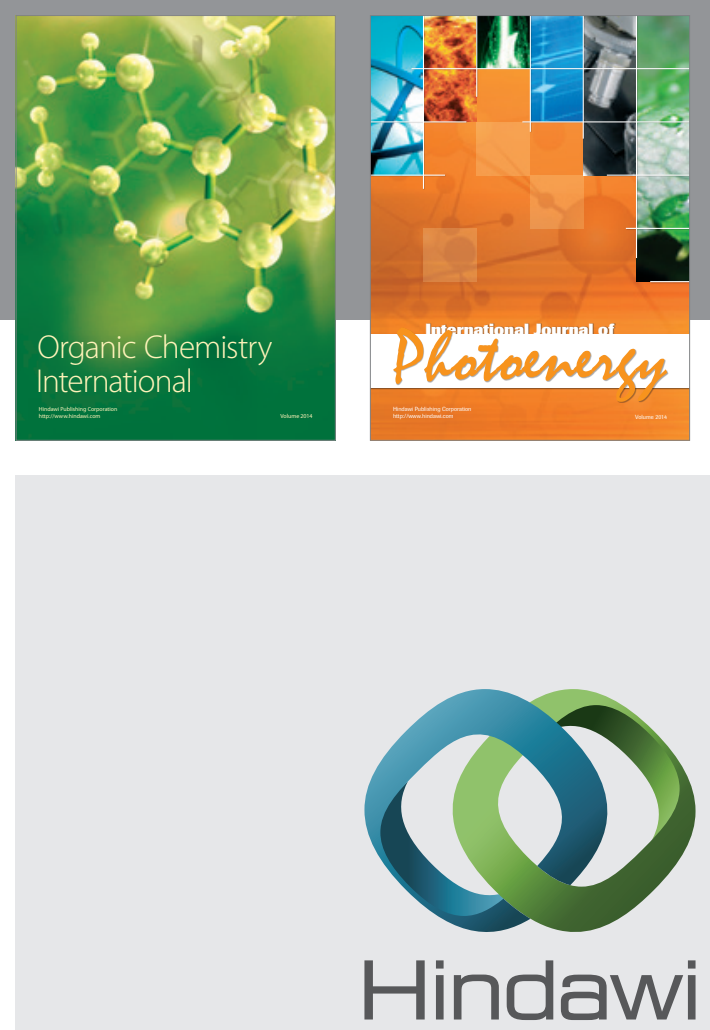

Submit your manuscripts at

http://www.hindawi.com
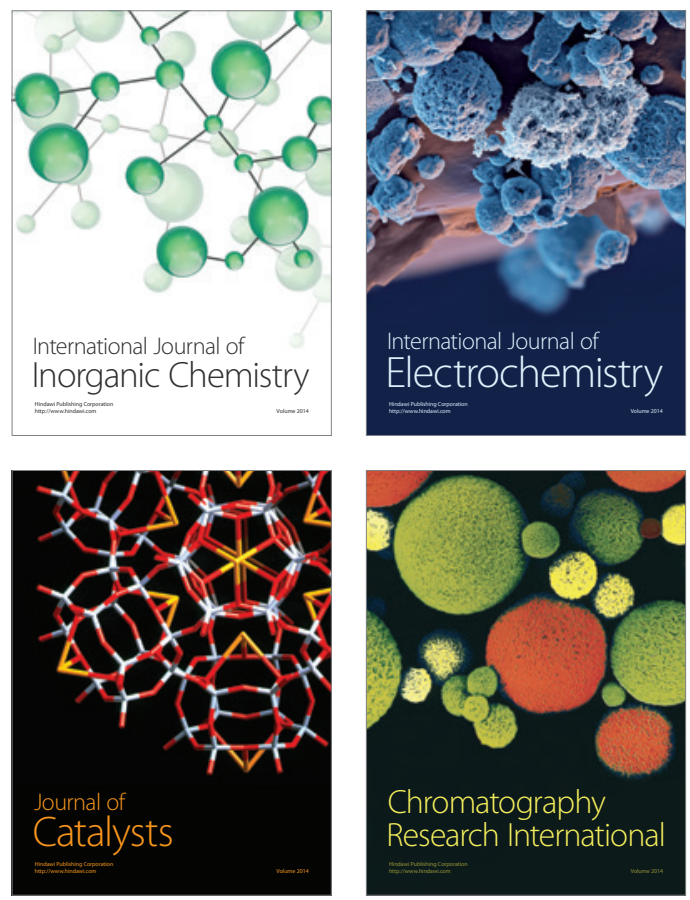
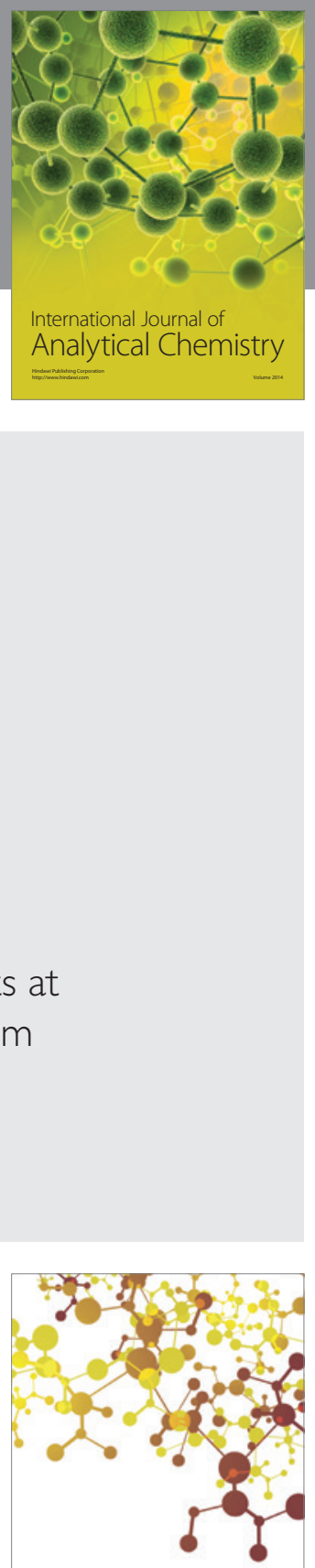

Journal of

Applied Chemistry
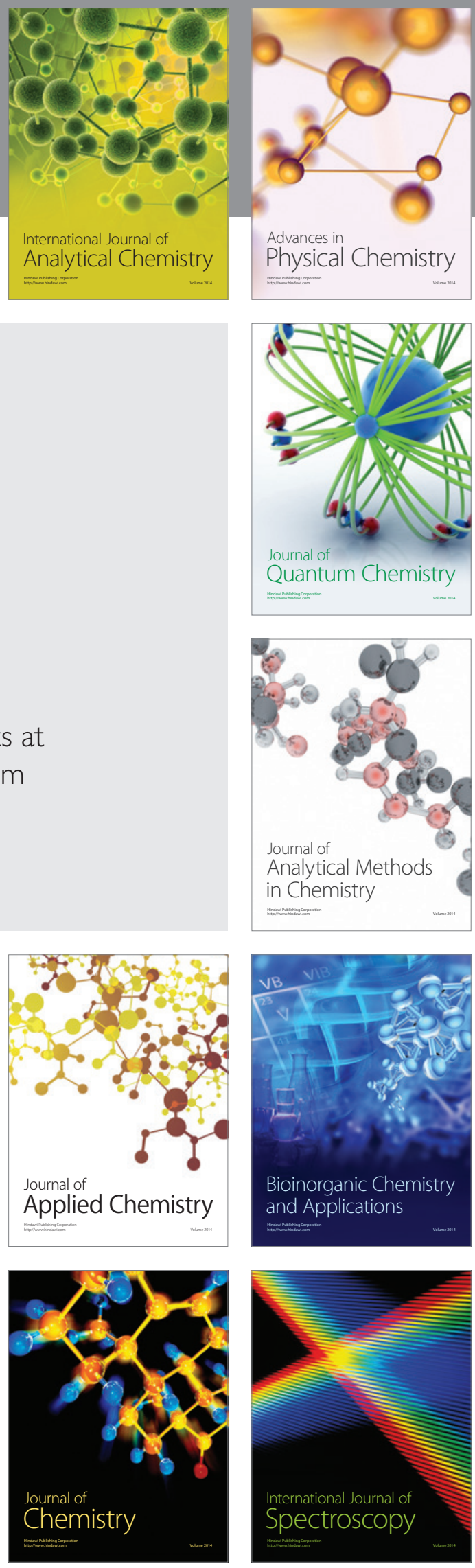